\title{
Greenhouse talks edge towards targets
}

[MUNICH \& TOKYO] Little public progress was made towards agreement on binding targets for reducing greenhouse gas emissions during the seventh round of international negotiations on implementing the Rio climate treaty of 1992, which took place in Bonn last week.

But there was some guarded optimism at the end of the meeting that the gap between participants in the discussion may be closing to an extent that such targets can be agreed at the ministerial-level meeting due to take place in Kyoto, Japan, in December.

The US Senate, which would have to ratify any agreement, continues to warn against letting developing countries off the hook. But President Bill Clinton last week told a press conference in Washington that the Kyoto meeting "must take all concrete steps" to address the problem of man-made climate change. "The United States must commit to realistic and binding limits on our emissions of greenhouse gases," Clinton said. "The science demands that we act."

The position of Japan, the host nation for the Kyoto meeting, remains unclear. During the Bonn sessions, Japan's major daily newspaper, Yomiuri Shinbun, reported that Japan had proposed informally a strategy to the United States under which all those countries whose emissions are currently below a per capita limit of 3 tonnes would have until 2010 to stabilize per capita emissions at their 1990 levels.
If this proposal were adopted, those countries' absolute emissions — including Japan's - could grow in proportion to their population growth over this period. But countries now above the 3 tonnes limit would have to reduce their emissions to a level at or below 1990 levels in absolute terms by 2010 . For the period between 2010 and 2015, governments could choose between either reducing their per capita emissions to under 3 tonnes, or stabilizing emission levels at 1990 levels.

Although it is widely assumed that this proposal represents the position of Japan's powerful Ministry of International Trade and Industry, many feel that it is unlikely to be politically acceptable either in Japan where there is domestic criticism of the country's relatively weak stand on the climate issue - or with its industrialized partners, which might feel that they were letting Japan off the hook.

Japanese officials have denied the newspaper's report of a firm Japanese proposal, and at a press conference in Bonn the director general of the Japanese Environmental Agency, Ishii Michiko, did not comment on the issue. According to a follow-up report in the newspaper, the German delegation to the Bonn meeting refused to discuss the proposals, saying that it would "not consider anything that has already been reported on in the press".

The final session of the Bonn meeting heard a potentially significant statement from the Africa group accepting the need for a "globally agreed ceiling" of greenhouse gas emissions, provided that this is based on a convergence on an agreed timescale between reduced emissions from industrialized countries and a "controlled growth" of future emissions from developing countries.

Speaking on behalf of African countries, the Zimbabwean delegate, Rungano Karamanzera, deputy director of the department of meteorological services in Harare, expressed the belief that "this will take us along a path to responsible climate management that allows us to reach our goal of defining a mutually agreed point of convergence and sustainable development".

Last week's sessions also saw detailed discussions about emissions inventory methodologies. The climate convention's Subsidiary Body on Science and Technology proposed that there should be a stronger policy on the scientific aspects of monitoring and reporting emissions. To increase such work, the scientific staff at the United Nations' climate secretariat in Bonn is likely to be doubled, from three to six.

The final preparatory meeting before the Kyoto meeting will take place in Bonn in October. Intense discussions are generally expected at that point, as neither the United States nor Japan is likely to reveal details of their greenhouse-gas reduction targets beforehand. QuirinSchiermeier \& Robert Triendl

\section{Head of French leukaemia inquiry quits after partisan remarks}

[PARIS] The chairman of a commission of inquiry investigating claims of a slight increase in leukaemias among children living close to the nuclear reprocessing plant at La Hague, on France's northern coast, has resigned following a series of public statements voicing his doubts about the scale of the danger.

The inquiry was set up earlier this year by the ministries of health and of the environment under the former government of Alain Juppé following the publication of the claims in the British Medical Journal in January by a team headed by Jean-François Viel of the University of Besançon.

Officials say that the resignation of Charles Souleau, dean of the Faculty of Pharmacy in Chateny-Malabry outside Paris, is unlikely to have a significant impact on the work of the commission. The inquiry is focusing on two particular aspects: radioecology, under the direction of Annie Sugier of the Institute of Nuclear Protection, and safety and epidemiology, under André Spira of the medical research agency INSERM. Both were nominated by the government last week.

Souleau's departure is the logical consequence of the public stance he has adopted. In a letter to other members of the committee, he spoke of the "totalitarian vision of the greens", comparing them to "a fundamentalist sect".

During a public meeting in June attended by local councillors from the NordCotentin region in which La Hague is situated, he used conclusions based on a model produced by Cogema, the contractor that operates the reprocessing plant, to argue that the epidemiological risk around the plant was minimal. He challenged the quality of Viel's research, but said Viel had been a victim of an "anglophone lobby" which "controls scientific publications".

Viel says that he does not doubt the intellectual honesty of Souleau, but argues that he has "confused divergences of opinion with strong pressures, which has upset him and pushed him off course". Viel points out that his research was justified by epidemiological analyses carried out in the United Kingdom in 1984 around the reprocessing facilities at Sellafield and Dounreay. It was therefore logical to carry out a similar study around the French plant.

This view is shared by Sugier, who points out that Viel has not reached any definitive conclusion and that he was merely putting forward a hypothesis on how the leukaemias might be linked to the nuclear activities.

Sugier says it is important to verify both Viel's results and his hypothesis. The real problem appears to be the nature of the data, which are based on the medical registers of the region. These registers are the property of individual doctors, describing how an illness spreads. There are relatively few of them, and they frequently lack rigour in the recording of the data.

The major effort now is to focus on these data and on calculations of dosage based on them. This has the support of Bernard Cazeneuve, parliamentary representative for Cherbourg and chair of a special commission on information about $\mathrm{La}$ Hague, which is drafting a bill to be presented to parliament in the autumn on health monitoring in France. 